\title{
CLASSIFICATION-CARD MEDIA: ITS EFFECT TOWARDS LEARNING ACHIEVEMENT IN BIOLOGY SUBJECT
}

\author{
Lia Angela ${ }^{1 *}$, Mitra Noveri ${ }^{2}$, Tiara $^{3}$ \\ ${ }^{1,2,3}$ Department of Biology Education Faculty of Education and Teacher Training, Institut Agama Islam \\ Negeri Kerinci, Indonesia \\ *Corresponding author: liaangela@iainkerinci.ac.id
}

\begin{tabular}{|c|c|}
\hline Article Info & ABSTRACT \\
\hline Article history: & \multirow{8}{*}{$\begin{array}{l}\text { This research aims to determine the effect of the application of } \\
\text { classification card media to the learning achievement. This research } \\
\text { is a quasi-experimental study. The population of this research is the } \\
\text { students of class X Science of SMA Negeri } 7 \text { Kerinci. The sample } \\
\text { class is students of Class X Science } 1 \text { as an experimental class and } \\
\text { Class X Science } 2 \text { as a control class. The research instrument is a } \\
\text { test with objective questions. The final test result data were } \\
\text { analyzed using t-test. The results of the t-test analysis showed that } \\
\text { the application of the classification card media could improve } \\
\text { student learning achievement. }\end{array}$} \\
\hline Received: February 4, 2020 & \\
\hline March & \\
\hline Published: March 30, 2020 & \\
\hline Keywords: & \\
\hline Classifi & \\
\hline Learni & \\
\hline Learning achievement & \\
\hline
\end{tabular}

Biology subject

\begin{tabular}{|c|c|}
\hline \multicolumn{2}{|c|}{$\begin{array}{c}\text { MEDIA KARTU KLASIFIKASI: PENGARUHNYA TERHADAP } \\
\text { CAPAIAN BELAJAR BIOLOGI }\end{array}$} \\
\hline & ABSTRAK \\
\hline \multirow{6}{*}{$\begin{array}{l}\text { Kata Kunci: } \\
\text { Kartu klasifikasi } \\
\text { Media pembelajaran } \\
\text { Hasil belajar } \\
\text { Biologi }\end{array}$} & hengetahui \\
\hline & klasifikasi terhadap hasil belajar biologi sis \\
\hline & ini menggunakan metode quasi ek: \\
\hline & $\begin{array}{l}\text { mengambil Populasi yaitu siswa kelas X IPA SMA Negeri } 7 \\
\text { Kerinci Kelas samnel vaitu siona kelas X IPA } 1 \text { dan klas X IP }\end{array}$ \\
\hline & 2. Instrumen penelitian yang digunakan adalah tes dengan soal \\
\hline & $\begin{array}{l}\text { objektif. Data hasil tes akhir dianalisis menggunakan uji-t. Hasil } \\
\text { penelitian menunjukkan bahwa penerapan media kartu klasifikasi } \\
\text { dapat meningkatkan capaian belajar biologi siswa. }\end{array}$ \\
\hline
\end{tabular}

(C) 2020 Unit Riset dan Publikasi Ilmiah FTK UIN Raden Intan Lampung

\section{INTRODUCTION}

Biology is the study of living things, and the interactions between them and their environment [1]. Biology helps students to understand whatever happens with themselves and nature. This understanding is obtained by students through learning, through interaction and information exchange between teachers and students [2]. So, in the learning process, the teacher not only conveys information about the theory, but also must strive to make the information into a learning activity that can be fun and easily accepted by students, so as to maximize student learning achievement [3]. For this reason, teachers are required to have the ability to design learning that is suitable for students' needs, one of which is by utilizing learning media that is appropriate to the character of students. 
Learning media are all things that can bring information or messages in interaction in the learning process. The use of learning resources and learning media is a strategy in learning that can help to achieve learning purposes [4]. The use of learning media can increase interest and student attention in learning, so that it can foster motivation to learn, allow students to interact directly with their environment, and make students learn independently based on their abilities and interests. The use of appropriate media can help to achieve one of the goals of learning biology, it is the ability to classify. The ability to classify is an important ability in the process of learning science, especially biology. The ability to classify can help students to distinguish, identify, classify, categorize, connect concepts and others [5].

One subject in the study of biology that requires the ability to classify is the Magnoliophyta chapter. This chapter is considered quite difficult to understand because there are parts that must be studied in the system of classification, identification and nomenclature. Not only in understanding, students also have difficulty in remembering plant terms because they use Latin. Concepts and vocabulary in biology prevent students from understanding the theory [6]. This has an impact on student learning outcomes. Based on observations at state high schools in Kerinci Regency, especially in learning biology, in the school environment there are many Magnoliophyta plants, Magnolophyta plants that are around school can be used as learning resources in the Magnoliophyta chapter. Learning results in one of the senior high schools in Kerinci Regency, showed that the average score of class X student for Magnoliophyta chapter were low and below the school minimum standard. To minimize students' difficulties in understanding the theory, a strategy is needed to sort and group plants according to their characteristics. One strategy that can be used is by using simple and attractive media, such as classification card media. Some research results show that the use of card media helped students to remember biology theory more effectively [7] [6] [8].

Based on research results using phylum identification cards, it helped students to identify animals and helped students constructed traits through inductive and deductive thinking. This media can help to improve student understanding and reduce student cheating in learning [5]. The results of previous study using classification cards in the learning process prove that there is an increase in student learning outcomes both in cognitive and affective aspects through classroom action research [9]. Other research that use card media in practical activities prove that card media helped students deduce practical results because it can trigger students to come up with creative ideas and help students in mastering skills in practical activities [10]. Picture card media can stimulate student creativity, so students are interested in learning [11].

Learning Biology uses the Living Classification Card media which is implemented by distributing cards that contain a sequence of classifications of living things consisting of: divisions or phyla to species, pictures of species, and characteristics of each species. The use of this media allows students to learn by playing. Playing in learning has important values that cannot be ignored [6]. Thus, students do not feel bored and can learn independently, and do not depend on the teacher's explanation. Based on those reasons, the purpose of this study is to determine the differences in student learning achievement that use the classification card media and those that do not use the classification card on Magnoliophyta chapter. 


\section{METHOD}

The type of this research is quantitative with quasi-experimental methods. The design of this study was the Post-test Only Control Group Design. The study was conducted in two class groups, the experimental class and the control class. Then, learning by using the classification card media is conducted in the experimental class and learning without using the classification card media is conducted in the control class. At the end of learning, both classes are given a final test (posttest) to see student learning outcomes after treatment and a final test (posttest). The study design can be seen in Table 1 .

Table 1. Research Design

\begin{tabular}{ccc}
\hline Class & Treatment & Posttest \\
\hline Experimental & $\mathrm{X}$ & $\mathrm{T}$ \\
Control & - & $\mathrm{T}$ \\
\hline
\end{tabular}

\section{Information:}

$\mathrm{Q}=$ posttest to measure improvement in learning outcomes in both classes.

$\mathrm{X}=$ the treatment given to the experimental class using the classification card media.

The population in this study were all students of class X Science in SMAN 7 Kerinci. The sample is determined using cluster random sampling technique. The instrument used to collect the data was the final test (posttest) in the experimental class and the control class to see student learning achievement. The test is in the form of objective questions. Before the final test is given to the sample class, the test is tested first. For trial tests, the tests were conducted in class XI Science 2 of SMA Negeri 7 Kerinci. The data analysis technique used is normality test, homogeneity test, and hypothesis test. To test hypotheses towards learning outcomes, we use the $t$ test.

\section{RESULTS AND DISCUSSION}

Classification card learning is carried out in parallel between the control class and the experimental class with four meetings. In the experimental class, magnoliophyta learning uses classification card media, while magnoliophyta learning in the control class does not use classification card media. At the final meeting (in the fifth meeting), a final test was held to measure student learning achievements. The learning achievements of students in class X Science 1 and X Science 2 can be seen in Table 2.

Table 2. Student Post-Test Results

\begin{tabular}{llllll}
\hline Class & $\boldsymbol{N}$ & $\overline{\boldsymbol{x}}$ & $\boldsymbol{S}$ & $\boldsymbol{X}_{\boldsymbol{m i n}}$ & $\boldsymbol{X}_{\boldsymbol{m a x}}$ \\
\hline Control & 36 & 72,78 & 7,67 & 50 & 90 \\
Experiment & 33 & 78,18 & 9,95 & 60 & 90 \\
\hline
\end{tabular}

Based on Table 2, the average score of students in the experimental class was 78.18, higher than the score of students in the control class that was 72.78. So, the learning outcomes of students who use the classification card media have reached the minimum completeness criteria of SMA N 7 Kerinci, which is 75.

The differences in the learning achievements of the control class and the experimental class were carried out by using the t-test, normality test and homogeneity test. Normality test results can be seen in Table 3.

Table 3. Normality Test Results

\begin{tabular}{ccccc}
\hline Class & $\boldsymbol{N}$ & $\boldsymbol{L o}$ & $\boldsymbol{L t}$ & Conclusion \\
\hline Control & 36 & 0,1073 & 0,147 & Normal \\
Experiment & 33 & 0,1362 & 0,154 & Normal \\
\hline
\end{tabular}


Based on Table 3. The normality test results are stated to be normally distributed because $\mathrm{L}_{\mathrm{o}}<\mathrm{L}_{\mathrm{t}}$. Homogeneity test is done after the normality test. Homogeneity test using $\mathrm{F}$ test. Homogeneity analysis results obtained are $F_{\text {count }}=1.68$ and $F_{\text {table }}=1.80$, it can be concluded that the data from the experimental class (using the classification card media) and the control class (not using the classification card media) have homogeneous variances at a $95 \%$ confidence level.

Hypothesis testing is done to determine differences in student learning achievements in the sample class. Hypothesis test results with the t-test can be seen in Table 4 .

Table 4. T-test results

\begin{tabular}{lccl}
\hline Class & $\boldsymbol{t}_{\text {count }}$ & $\boldsymbol{t}_{\text {table }}$ & $\boldsymbol{S}$ \\
\hline Post-test & 2,52 & 1,66 & 8,93 \\
\hline
\end{tabular}

Based on Table $4, t_{\text {count }}>t_{\text {table }}$ so, it can be concluded that there are differences in learning achievements in students who learn with classification card media with students who study without classification cards. This difference in learning outcomes indicates that the use of classification cards influences student learning achievements. The improvement of students' learning achievements who learn by using the classification card media became so high because the classification card is one of the learning strategies created by researchers by adapting a game. Learning that uses media can make learning becoming more meaningful, because the lesson delivered can be more easily understood by students [12]. The purpose of classification is to help students recognize, classify and study the taxonomy of living things [13]. The use of classification card media can attract students' attention, interests and responses to the learning process so that the learning process becomes more interactive. Learning with science edutainment plant-based smart cards can increase students' interest in learning, and make students' concept understanding increase [14]. Learning by applying cards as learning media can provide direct experience to students, so that the information conveyed can be contextually accepted by students [15]. The use of card media in the learning process helps students understand subject matter more easily, increasing the enthusiasm, attention and interest of students in learning [16]. Different results appear to the control class that during the learning process in the magnolyphyta chapter did not use the classification card media, so students become bored and have difficulty in understanding learning material and make students unable to understand the material contextually

\section{CONCLUSION}

The use of classification card media in learning in magnoliophyte chapter shows that there are differences in learning achievements between the control class and the experimental class. The test results show that the learning achievements in the experimental class 1 are better than the control class. The average post test score of the experimental class was 78.18 and the control class was 72.78 . It can be concluded the classification card media can stimulate students' creative ideas and help students to understand the theory, because the classification card media is designed with colorful visuals and attractive images. Therefore, it is recommended for teachers to use instructional media that are designed by the themselves in the learning process in school. 


\section{REFERENCES}

[1] L. A. Urry, M. L. Cain, S. A. Wasserman, P. V. Minorsky, and J. B. Reece, Campbell Biology, 11th ed. New York: Pearson, 2016.

[2] Tiara et al., "Utilization of environment as a learning media or natural science study in junior high schools," Int. J. Sci. Technol. Res., vol. 9, no. 2, pp. 1981-1983, 2020.

[3] S. Setyaningsih, "Peningkatan Aktifitas dan HAsil Belajar Bentuk PAsar dengan Metode Course Review Horay (CRH) Berbantuan Media Gambar Kelas VIII SMP N 1 Bulu Kabupaten Sukoharjo," Econ. Educ. Anal. J. http//journal.unnes.ac.id/sju/index.php/eeaj PENINGKATAN, vol. 2, no. 3, pp. 124-136, 2014.

[4] R. Ansyar, Kreatif Mengembangkan Media Pembelajaran. Jakarta: Gema Persada Press, 2012.

[5] L. Oktavia, L. Putri, K. I. Filum, L. Octavia, and K. Kunci, "Kartu Indentifikasi Filum Sebagai Media Pembelajaran Yang Inovatif Untuk Mempelajari Materi Klasifikasi Hewan Card of Identification Phylum As an Inovative Media To Study Animal Classifications," vol. 2, no. 1, pp. 2442-3750, 2016.

[6] A. F. Gutierrez, "Development and effectiveness of an educational card game as supplementary material in understanding selected topics in biology," CBE Life Sci. Educ., vol. 13, no. 1, pp. 76-82, 2014, doi: 10.1187/cbe.13-05-0093.

[7] W. Astuti, L. F. Yeni, and E. Aryati, "Pengaruh Media Kartu Bergambar Terhadap Hasil Belajar Siswa pada Materi Jamur di SMA," J. Pendidik. dan Pembelajaran, vol. 2, no. file:///I:/3/ana/1784-4269-1-SM.pdf file:///I:/3/ana/37-126-1-PB.pdf file:///I:/3/ana/364-49-645-1-10-20170220.pdf, pp. 1-9, 2013.

[8] S. H. Su, TzuFen, Cheng, Meng Tzu Lin, "Investigating the effectiveness of an educational card game for learning how human immunology is regulated," CBE Life Sci. Educ., vol. 13, no. 3, pp. 504-515, 2014, doi: 10.1187/cbe.13-10-0197.

[9] R. P. Hendrastuti, "Penerapan MK2MH untuk Meningkatkan Hasil Belajar Biologi Materi Klasifikasi Makhluk Hidup Siswa Kelas VII A SMP Muhammadiyah 2 Surakarta Tahun Ajaran 2010/2011," Universitas Muhammadiyah, 2011.

[10] E. B. Wasilah, "Peningkatan kemampuan menyimpulkan hasil praktikum ipa melalui penggunaan media kartu," J. Pendidik. IPA Indones., vol. 1, no. 1, pp. 8290, 2012, doi: 10.15294/jpii.v1i1.2018.

[11] A. Budiarti, R. S., Sadikin, "Pengaruh Kartu Kwartet Animalia dengan Model TGT terhadap Pemahaman Materi Taksonomi Hewan Siswa SMAN 8 Kota Jambi," J. BIODIK, vol. I, no. September, pp. 1-9, 2015.

[12] S. Sediasih, "Meningkatkan Hasil Belajar Siswa dengan Menggunakan Model Make A Match pada Mata Pelajaran PKN di Kelas V SDN Karyawangi 2," JPSD, vol. 3, no. 1, pp. 74-81, 2017.

[13] M. Rohwati, "Penggunaan Education Game untuk Meningkatkan HAsil Belajar IPA Biologi Konsep Klasifikasi Makhluk Hidup," J. Pendidik. IPA Indones., vol. 1, no. 1, pp. 75-81, 2012.

[14] N. H. M. Umar, P. Parmin, and I. U. Wusqo, "Unnes Science Education Journal," Unnes Sci. Educ. J., vol. 5, no. 2, pp. 1288-1297, 2016.

[15] S. Muhibbi, U. Faizah, and A. N. Maulida, "Pengaruh Media permainan Kartu Pintar terhadap ketuntasan Belajar Siswa pada Materi Klasifikasi TumbuhTumbuhan," E-journal Pensa, vol. 5, no. 3, pp. 1-5, 2017.

[16] D. Y. Sativa, "Penggunaan Media Kartu Untuk Meningkatkan Hasil Belajar Geografi Siswa Kelas Xi Ips 1,”pp. 1-21, 2012. 